\title{
Pengaruh Komponen Kecerdasan Emosional pada Pemahaman Akuntansi
}

\author{
Made Sukma Mutiara Pramita Sari ${ }^{1}$ \\ Dewa Gede Wirama
}

\author{
${ }^{1,2}$ Fakultas Ekonomi dan Bisnis Universitas Udayana (Unud), Bali, Indonesia \\ e-mail: sukmamutiaras@yahoo.co.id
}

\begin{abstract}
ABSTRAK
Pendidikan akuntansi di perguruan tinggi bertujuan untuk mendidik mahasiswa agar menjadi seorang akuntan profesional yang memiliki pengetahuan yang luas di bidang akuntansi. Pemahaman akuntansi merupakan kemampuan untuk memahami akuntansi baik sebagai pengetahuan maupun sebagai proses atau praktik. Pemahaman akuntansi seseorang dapat dipengaruhi oleh kecerdasan emosional yang terdapat pada diri masing-masing. Tujuan penelitian ini adalah untuk mengetahui pengaruh komponen kecerdasan emosional pada pemahaman akuntansi. Penelitian dilakukan di Fakultas Ekonomi dan Bisnis Universitas Udayana. Jumlah sampel yang diambil sebanyak 111 mahasiswa. Metode penentuan sampel yang digunakan yaitu metode non probability sampling. Pengumpulan data dilakukan melalui kuesioner. Teknik analisis data yang digunakan adalah analisis regresi linear berganda. Berdasarkan hasil analisis ditemukan bahwa komponen kecerdasan emosional berpengaruh positif pada pemahaman akuntansi. Hal ini menunjukkan semakin tinggi pengenalan diri, pengendalian diri, motivasi, empati dan keterampilan sosial seseorang maka semakin tinggi pemahaman akuntansinya.
\end{abstract}

Kata kunci: Akuntansi, kecerdasan emosional, mahasiswa akuntansi.

\begin{abstract}
Accounting education in college is intended to educate students to work as professional accountants with knowledge in accounting. Understanding of accounting is the process to understand accounting both as knowledge and as a process or practice. Understanding of accounting can be influenced by emotional intelligence of each individual. The purpose of this study is to determine the effect of the components of emotional intelligence on accounting understanding. This research was conducted at the Faculty of Economics and Business, Udayana University. The number of samples was 111 students, using non probability sampling methods. Data collection is conducted through a questionnaire. The data analysis technique used is multiple linear regression analysis. Based on the results of the analysis it was found that the components of emotional intelligence had positive effects on accounting understanding. The higher self-recognition, self-control, motivation, empathy and social skills, the higher the understanding of accounting.

Keywords: Accounting, emotional intelligence, accounting students.
\end{abstract}

\section{PENDAHULUAN}

Akuntansi merupakan hal penting yang saat ini banyak diminati oleh mahasiswa.

Rata-rata mahasiswa memilih akuntansi karena keinginan untuk menjadi profesional dalam bidangnya (Yanti, 2014). Dalam perkembangan akuntansi, bidang yang paling awal berkembang adalah akuntansi keuangan. Seiring dengan 
perkembangan industri yang sangat pesat karena kebutuhan akan informasi, maka berkembanglah bidang-bidang lain, seperti akuntansi biaya, akuntansi manajemen, auditing, akuntansi perpajakan, akuntansi sektor publik, sistem informasi akuntansi, akuntansi keperilakuan dan perkembangan terakhir khususnya di Indonesia adanya konsep akuntansi syariah. Akuntansi dapat dipandang dari berbagai sudut pandang sehingga memperkaya bidang akuntansi (Putri, 2008).

Akuntansi keperilakuan merupakan bagian dari akuntansi yang mengintregasikan dimensi perilaku dengan akuntansi tradisional. Studi-studi mengenai perilaku memberikan pencerahan penting pada karakteristik dan penyebab perilaku manusia yang dimana mungkin dapat berpengaruh pada cara kerja akuntan nantinya. Kinerja akademik siswa di berbagai bidang, level, dan universitas adalah faktor pendidikan (Azizollah, 2013). Jones (2009) menyatakan perlu menyediakan akademisi dengan pengetahuan serta keterampilan untuk meningkatkan dan mendorong pengembangan kecerdasan pada mahasiswa.

Rachmi (2010) mendefinisikan kecerdasan emosional sebagai komponen yang membuat seseorang menjadi pintar menggunakan emosinya. Menurut Cetin (2016) kecerdasan emosional adalah kemampuan lebih yang dimiliki oleh seseorang dalam memotivasi diri, ketegaran dalam menghadapi kegagalan, kemampuan mengendalikan emosi dan menunda kepuasan serta mengatur keadaan jiwa. Secara umum, kecerdasan emosional adalah seluruh kemampuan untuk membantu memahami dan mengendalikan emosi diri sendiri dan orang lain untuk memberikan perkembangan intelektual dan emosional (Bay dan Mckeage, 2006). Kecerdasan emosional telah dibahas dalam banyak studi akademik melalui 
kontribusi ilmiah yang dibuat dari berbagai aspek terutama setelah akhir 1990-an. Studi-studi ini dimulai dengan pengukuran kecerdasan emosional individu dan adaptasinya terhadap kehidupan profesional di bawah bimbingan pencipta kecerdasan emosional Salovey, Mayer, Caruso dan Goleman, dan dipertahankan dengan penemuan hubungan kecerdasan emosional dengan berbagai variabel seperti prestasi akademik, karakteristik demografis, perilaku organisasi, kelelahan profesional, dan kinerja di tempat kerja (Durgut, et al., 2013).

Menurut Salovey dan Mayer (dalam Stein dan Howard, 2002) pencipta istilah "kecerdasan emosional", mendefinisikan kecerdasan emosional adalah kemampuan untuk mengenali perasaan, meraih dan membangkitkan perasaan untuk membantu pikiran, memahami perasaan dan maknanya, dan mengendalikan perasaan secara mendalam sehingga membantu perkembangan emosi dan intelektual. Emosi dan pikiran tidak saling bertentangan, mereka memiliki hubungan yang erat satu sama lain (Ashkanasy, et al., 2002). Kecerdasan emosional menunjuk pada kemampuan untuk mengenali dan membedakan perasaan, kegembiraan, makna dan konsep hubungan di antara mereka (Khaledian, et al., 2013).

Emosi meliputi reaksi yang tidak terduga bersama dengan kondisi emosional yang menyenangkan atau tidak menyenangkan (Khaef dan Ahmadali, 2003). Kemampuan-kemampuan ini mendukung seorang mahasiswa dalam mencapai tujuan dan cita-citanya. Goleman (2003) menyatakan bahwa kemampuan akademik bawaan, nilai rapot, dan prediksi kelulusan pendidikan tinggi tidak memprediksikan seberapa baik kinerja seseorang sudah bekerja atau 
seberapa tinggi sukses yang dicapainya dalam hidup. Kecerdasan emosional yang berangsur-angsur telah menjadi salah satu faktor terpenting untuk mencapai kesuksesan dalam organisasi karena orang-orang yang cerdas secara emosional merupakan sumber keunggulan kompetitif (Agrawal dan Khan, 2015).

Kecerdasan emosional yang membuat perbedaan cara menyelesaikan masalah pada seseorang, dari penyelesaian masalah dalam hidup, pekerjaan dan mengembangkan keterampilan (Modassir, 2008). Dalam proses tersebut mahasiswa dapat paham dengan apa yang akan digunakan nantinya dalam memasuki dunia kerja yang sesungguhnya juga perlu untuk memastikan bahwa mereka yang lulus siap untuk memulai profesi (Pan dan Hector, 2011). Kecerdasan emosional pada pemahaman akuntansi berdasarkan penelitian Horri dan Esti (2018) bahwa kecerdasan emosional berpengaruh terhadap tingkat pemahaman akuntansi sejalan dengan penelitan Wiwin dan Ernawati (2007) bahwa adanya pengaruh signifikan antara kecerdasan emosional terhadap tingkat pemahaman akuntansi. Penelitian Fahrianta dan Syam (2012) bahwa kecerdasan emosional tidak berpengaruh secara signifikan terhadap tingkat pemahaman akuntansi sejalan dengan penelitian (Widyawati, dkk, 2014) kecerdasan emosional berdasarkan indikator pengendalian diri dan empati berpengaruh terhadap tingkat pemahaman akuntansi sedangkan indikator yang lain yaitu pengenalan diri, dan keterampilan sosial terbukti tidak berpengaruh ini menunjukan bahwa kecerdasan emosional tidak sepenuhnya mampu meningkatkan pemahaman akuntansi. Penelitian tentang kecerdasan emosional pada pemahaman akuntansi dengan variabel independen pengenalan diri, pengendalian diri, motivasi, empati, 
keterampilan sosial telah dilakukan oleh peneliti sebelumnya. Penelitian yang dilakukan oleh Rachmi (2010) menyatakan bahwa pengenalan diri berpengaruh signifikan terhadap pemahaman akuntansi. Berbeda dengan penelitian Julino (2013) yang menyatakan bahwa pengenalan diri tidak berpengaruh terhadap pemahaman akuntansi. Penelitian Nuraini (2007) menyatakan bahwa pengendalian diri berpengaruh terhadap pemahaman akuntansi, namun penelitian Mulyani (2017) menyatakan bahwa pengendalian diri tidak berpengaruh pada pemahaman akuntansi.

Penelitian Manansal (2013) menyatakan motivasi berpengaruh pada pemahaman akuntansi, sebaliknya Rahayu, dkk (2008) menyatakan motivasi tidak berpengaruh pada pemahaman akuntansi. Penelitian Wiyono (2012) menyatakan bahwa empati berpengaruh pada pemahaman akuntansi, sebaliknya Melandy (2007) menyatakan bahwa empati tidak berpengaruh pada pemahaman akuntansi. Penelitian Manitri (2008) menyatakan bahwa keterampilan sosial berpengaruh pada pemahaman akuntansi, sebaliknya Constanty (2017) yang menyatakan bahwa keterampilan sosial tidak berpengaruh pada pemahaman akuntansi.

Komponen kecerdasan emosional yaitu pengenalan diri, pengendalian diri, motivasi, empati, keterampilan sosial. Pengenalan diri bertujuan agar seseorang mampu dan bisa mengakui adanya kelebihan dan kekurangan pada diri setiap orang, juga agar bisa mengakui persamaan hak, kewajiban dan derajat dirinya dengan orang lain. Pengendalian diri merupakan tindakan mengendalikan atau mengarahkan tingkah laku seseorang dengan melakukan pertimbanganpertimbangan terlebih dahulu sebelum memutuskan sesuatu dengan 
mendisiplinkan kemauan atau dorongan-dorongan dalam diri, serta mengelola emosi, berhati-hati dan bertanggung jawab dalam bertindak guna mencapai hasil dan tujuan sesuai yang diinginkan. Motivasi merupakan dorongan yang timbul pada diri seseorang. Empati merupakan keadaan mental yang membuat seseorang untuk mengenali, mempresepsi, dan merasakan perasaan orang lain. Keterampilan sosial yaitu kemampuan individu untuk berkomunikasi efektif dengan orang lain baik secara verbal maupun nonverbal sesuai dengan situasi dan kondisi yang ada pada saat itu dimana keterampilan ini merupakan perilaku yang dipelajari. Kecerdasan emosional meningkatkan kemampuan individu untuk mengidentifikasi, mengelola, dan menggunakan emosi (Mahdi, et al., 2016).

Penelitian ini ditujukan untuk mengetahui bagaimana komponen kecerdasan emosional mempengaruhi mahasiswa dalam memahami pemahaman akuntansi. Pemahaman akuntansi secara teoritis merupakan kemampuan seseorang untuk memahami yang telah diajarkan oleh dosen yang akan mempengaruhi kecerdasan emosional orang tersebut dalam menyerap apa yang disampaikan oleh dosen. Penelitian ini berfokus kepada mahasiswa akuntansi dikarenakan peneliti berfokus pada bidang akuntansi.

Pemahaman akuntansi mahasiswa dinyatakan dengan seberapa mengerti seorang mahasiswa terhadap apa yang sudah dipelajari yang dalam konteks ini mengacu pada mata kuliah-mata kuliah akuntansi. Efisiensi akuntansi tergantung pada kualitas akuntan dan kualitas secara langsung dipengaruhi oleh tingkat kualifikasi dan pengetahuan mereka (Fallan dan Opstad, 2014). Fred, et al., (2012) mengemukakan tanda seorang mahasiswa memahami akuntansi tidak 
hanya ditunjukkan dari nilai-nilai yang didapatkannya dalam mata kuliah tetapi juga apabila mahasiswa tersebut mengerti dan dapat menguasai konsep-konsep yang terkait. Pendidikan akuntansi setidaknya dapat mempersiapkan peserta didik untuk memulai dan mengembangkan karir profesional dalam bidang akuntansi.

Dalam hal ini pemahaman akuntasi akan diukur dengan menggunakan nilai mata kuliah akuntansi yaitu pengantar akuntansi I, pengantar akuntansi II, akuntansi keuangan I, akuntansi keuangan II, akuntansi keuangan lanjutan, akuntansi biaya, akuntansi manajemen, pengauditan I, pengauditan II dan teori akuntansi. Mata kuliah tersebut merupakan mata kuliah yang didalamnya terdapat unsur-unsur yang menggambarkan akuntansi secara umum.

Saat ini telah banyak hal-hal berkembang dengan pesat, pandangan baru yang berkembang bahwa ada kecerdasan lain diluar kecerdasan intelektual (IQ) misalnya yaitu bakat, hubungan sosial, kematangan sosial dan lain sebagainya. Pada pandangan tradisional kecerdasan yaitu kemampuan membaca, menulis, dan berhitung dimana merupakan keterampilan angka dan kata yang diajarkan di pendidikan formal atau sekolah yang membimbing seseorang agar sukses di bidang akademis. Menurut Wibowo (2002) kecerdasan emosional adalah kecerdasan untuk menggunakan emosi sesuai dengan keinginan, kemampuan untuk mengendalikan emosi sehingga memberikan dampak yang positif dimana kecerdasan emosional dapat membuat diri merasakan emosi memahami dan membangkitkan perasaan. Menurut Salovey dan Mayer (dalam Stein dan Howard, 2002) pencipta istilah "kecerdasan emosional", mendefinisikan kecerdasan emosional adalah kemampuan untuk mengenali perasaan, meraih dan 
membangkitkan perasaan untuk membantu pikiran, memahami dan maknanya dan mengendalikan perasaan secara mendalam sehingga membantu perkembangan emosi dan intelektual. Kecerdasan emosional berkembang sesuai dengan umur dan pengalaman masa kanak-kanak sampai dengan usia dewasa. Kecerdasan adalah salah satu karakteristik utama yang menghasilkan perbedaan individu di antara orang-orang (Bakhtiarpor, 2009). Kecerdasan ini juga dapat dipelajari dan dikembangkan, dari beberapa pendapat diatas dapat dikatakan bahwa kecerdasan emosional menuntut diri untuk belajar mengakui dan menghargai perasaan diri sendiri dan orang lain dan untuk meresponnya dengan tepat dengan menerapkan secara efektif energi emosi dalam kehidupan dan pekerjaan sehari-hari.

Pengenalan diri merupakan dasar dari kecerdasan emosional yaitu merupakan kemampuan untuk membantu perasaan dari waktu ke waktu. Dalam menghadapi masa depan para mahasiswa akuntansi diharapkan mampu mengenal diri mereka sesuai dengan keterampilan dasar dari kecakapan emosi dengan demikian diharapkan mereka dapat belajar dengan sungguh-sungguh dan sadar sesuai dengan kemampuan dan kewajibannya serta mempunyai rasa percaya diri yang kuat. Goleman (2003) menyatakan bahwa kesadaran diri dalam mengenali perasaan sewaktu perasaan itu terjadi merupakan dasar kecerdasan emosional. Penelitian yang dilakukan oleh Febri, dkk (2014) menyatakan bahwa pengenalan diri berpengaruh terhadap tingkat pemahaman akuntansi. Hasil penelitian tersebut sejalan dengan penelitian Fanikmah (2016) yang menyatakan bahwa pengenalan diri berpengaruh positif pada pemahaman akuntansi. Berdasarkan penelitian tersebut, maka hipotesis penelitian yang dirumuskan sebagai berikut: 
$\mathrm{H}_{1}$ : Pengenalan diri berpengaruh positif pada pemahaman akuntansi.

Slovey (dalam Goleman, 2003) menyatakan bahwa mengelola emosi berarti menangani perasaan agar perasaan dapat terungkap dengan tepat, hal ini merupakan kecakapan yang sangat bergantung pada kesadaran diri. Berdasarkan uraian ini dapat diamsusikan bahwa pengendalian diri dapat mempengaruhi pemahaman akuntansi. Pengendalian diri mampu membuat mahasiswa menjadi seseorang yang lebih bertanggung jawan, berhati-hati atau teliti dalam mengerjakan tugas-tugasnya. Penelitian yang dilakukan oleh Nuraini (2007) ditemukan bahwa pengendalian diri berpengaruh positif terhadap tingkat pemahaman akuntansi. Penelitian Satria (2017) menyatakan pengendalian diri berpengaruh pada pemahaman akuntansi. Berdasarkan penelitian tersebut, maka hipotesis penelitian yang dirumuskan sebagai berikut:

$\mathrm{H}_{2}$ : Pengendalian diri berpengaruh positif pada pemahaman akuntansi.

Motivasi merupakan dorongan yang timbul pada diri seseorang sacara sadar atau tidak sadar untuk melakukan suatu tindakan dengan tujuan tertentu. Para mahasiswa yang memiliki upaya meningkatkan diri menunjukan semangat kearah penyempurnaan diri yang merupakan inti dari motivasi untuk meraih prestasi. Seorang mahasiswa yang termotivasi untuk berprestasi akan lebih jeli menemukan cara-cara untuk belajar lebih baik, untuk berusaha, untuk membuat inovasi, atau menemukan keunggulan kompetitif. Penelitian yang dilakukan oleh Manansal (2013) menyatakan bahwa motivasi berpengaruh pada tingkat pemahaman akuntansi sejalan dengan penelitian Trisnawati dan Suryaningrum (2003) menyatakan bahwa motivasi berpengaruh pada tingkat pemahaman 
akuntansi. Berdasarkan penelitian tersebut, maka hipotesis penelitian yang dirumuskan sebagai berikut:

$\mathrm{H}_{3}$ : Motivasi berpengaruh positif pada pemahaman akuntansi.

Dikalangan mahasiswa yang paling efektif dari empati adalah mempunyai kemampuan paling tinggi dalam penolakan terhadap sinyal-sinyal emosi tubuh sendiri mulai dari mendengar, memahami, dan bersosial dengan lingkungan kampus. Empati merupakan keadaan mental yang membuat seseorang untuk mengenali, mempresepsi, dan merasakan perasaan orang lain. Penelitian yang dilakukan oleh Wiyono (2012) menyatakan bahwa empati berpengaruh pada tingkat pemahaman akuntansi. Berdasarkan penelitian tersebut, maka hipotesis penelitian yang dirumuskan sebagai berikut.

$\mathrm{H}_{4:} \quad$ Empati berpengaruh positif pada pemahaman akuntansi.

Goleman (2003) menyatakan bahwa seni dalam membina hubungan dengan orang lain merupakan keterampilan sosial yang mendukung keberhasilan dalam pergaulan dengan orang lain. Tanpa memiliki keterampilan seseorang akan mengalami kesulitan dalam pergaulan sosial. Hal inilah yang dapat menyebabkan mahasiswa dapat belajar dengan suasana yang baik sehingga hasil yang dicapai dapat maksimal. Penelitian yang dilakukan oleh Wiwin dan Ernawati (2007) menyatakan bahwa keterampilan sosial berpengaruh pada pemahaman akuntansi. Penelitian oleh Manitri (2008) menyatakan bahwa keterampilan sosial berpengaruh positif terhadap tingkat pemahaman akuntansi. Berdasarkan penelitian tersebut, maka hipotesis penelitian yang dirumuskan sebagai berikut:

$\mathrm{H}_{5}$ : Keterampilan sosial berpengaruh positif pada pemahaman akuntansi. 


\section{METODE PENELITIAN}

Penelitian ini dilakukan di Fakultas Ekonomi dan Bisnis Universitas Udayana yang beralamat di Jalan P.B. Sudirman, Denpasar, Bali. Obyek penelitian ini adalah mahasiswa Reguler Denpasar Program Strata 1 Jurusan Akuntansi angkatan 2015 Fakultas Ekonomi dan Bisnis Universitas Udayana.

Populasi dalam penelitian ini adalah mahasiswa Reguler Denpasar Program Strata 1 Jurusan Akuntansi angkatan 2015 Fakultas Ekonomi dan Bisnis Universitas Udayana. Berdasarkan data yang diperoleh dari pihak fakultas, jumlah populasi mahasiswa Reguler Denpasar Program Strata 1 Jurusan akuntansi angkatan 2015 Fakultas Ekonomi dan Bisnis Universitas Udayana adalah sebanyak 152 mahasiswa yang aktif yang dapat diakses melalui https://simak.unud.ac.id. Mahasiswa Reguler Denpasar Program Strata 1 Jurusan akuntansi angkatan 2015 Fakultas Ekonomi dan Bisnis Universitas Udayana dipilih karena kini telah berada di akhir masa perkuliahan sehingga diharapkan memiliki gambaran mengenai pemahaman akuntansi. Sampel pada penelitian ini adalah sebanyak 111 mahasiswa yang didapat dari perhitungan menggunakan rumus Slovin.

Teknik analisis data yang digunakan dalam penelitian ini adalah Teknik analisis regresi linier berganda. Model regresi dalam penelitian ini ditunjukkan dengan persamaan sebagai berikut.

$Y=\alpha+\beta_{1} X_{1}+\beta_{2} X_{2}+\beta_{3} X_{3}+\beta_{4} X_{4}+\beta_{5} X_{5}$

Keterangan:

$\begin{array}{ll}\mathrm{Y} & =\text { pemahaman akuntansi } \\ \alpha & =\text { konstanta } \\ \mathrm{X}_{1} & =\text { pengenalan diri }\end{array}$




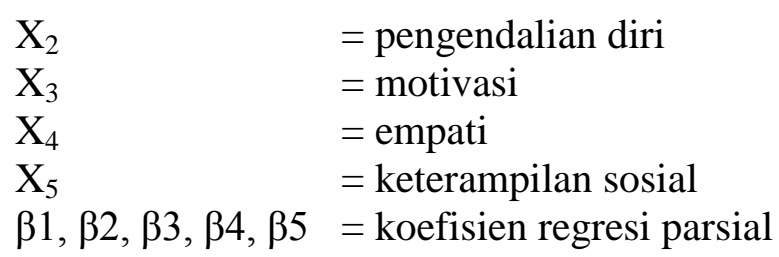

\section{HASIL DAN PEMBAHASAN}

Analisis statistik deskriptif digunakan untuk menggambarkan atau menjelaskan suatu data pada variabel penelitian terkait dengan nilai minimum, nilai maksimum, nilai rata-rata (mean), dan standar deviasi.

Tabel 1.

Hasil Analisis Statistik Deskriptif

\begin{tabular}{cccccc}
\hline Variabel & N & Min. & Max. & Mean & Std. Deviasi \\
\hline Pengenalan Diri & 111 & 20,0 & 40,0 & 34,820 & 3,5655 \\
Pengendalian Diri & 111 & 21,0 & 40,0 & 38,505 & 3,2386 \\
Motivasi & 111 & 20,0 & 40,0 & 37,225 & 3,4842 \\
Empati & 111 & 23,0 & 40,0 & 39,811 & 3,2656 \\
Keterampilan Sosial & 111 & 20,0 & 40,0 & 37,099 & 3,5547 \\
Pemahaman Akuntansi & 111 & 27,5 & 40,0 & 38,270 & 2,7092 \\
\hline Sumber: Data diolah 2018 & & & &
\end{tabular}

Variabel pengenalan diri memiliki nilai minimum sebesar 20 dan nilai maksimum sebesar 40 dengan nilai rata-rata sebesar 34,820. Nilai rata-rata sebesar 34,820 menunjukkan bahwa respon responden dalam menjawab pernyataan pada kuesioner cenderung merasa setuju pada masing-masing item pernyataan artinya pengenalan diri cenderung tinggi, yang berarti responden memiliki pengenalan diri yang baik. Standar deviasi pada variabel pengenalan diri adalah sebesar 3,5655. Hal ini menunjukkan bahwa standar penyimpangan data terhadap nilai rata-ratanya adalah 3,5655.

Variabel pengendalian diri memiliki nilai minimum sebesar 21 dan nilai maksimum sebesar 40 dengan nilai rata-rata sebesar 38,505. Nilai rata-rata sebesar 38,505 menunjukkan bahwa respon responden dalam menjawab 
pernyataan pada kuesioner cenderung merasa setuju pada masing-masing item pernyataan artinya pengendalian diri cenderung tinggi, yang berarti responden memiliki pengendalian diri yang baik. Standar deviasi pada variabel pengendalian diri adalah sebesar 3,2386. Hal ini menunjukkan bahwa standar penyimpangan data terhadap nilai rata-ratanya adalah 3,2386.

Variabel motivasi memiliki nilai minimum sebesar 20 dan nilai maksimum sebesar 40 dengan nilai rata-rata sebesar 37,225. Nilai rata-rata sebesar 37,225 menunjukkan bahwa respon responden dalam menjawab pernyataan pada kuesioner cenderung merasa setuju pada masing-masing item pernyataan artinya motivasi cenderung tinggi, yang berarti responden memiliki motivasi yang baik. Standar deviasi pada variabel motivasi adalah sebesar 3,4842. Hal ini menunjukkan bahwa standar penyimpangan data terhadap nilai rata-ratanya adalah 3,4842 .

Variabel empati memiliki nilai minimum sebesar 23 dan nilai maksimum sebesar 40 dengan nilai rata-rata sebesar 39,811. Nilai rata-rata sebesar 39,811 menunjukkan bahwa respon responden dalam menjawab pernyataan pada kuesioner cenderung merasa setuju pada masing-masing item pernyataan artinya empati cenderung tinggi, yang berarti responden memiliki rasa empati yang tinggi. Standar deviasi pada variabel empati adalah sebesar 3,2656. Hal ini menunjukkan bahwa standar penyimpangan data terhadap nilai rata-ratanya adalah 3,2656.

Variabel keterampilan sosial memiliki nilai minimum sebesar 20 dan nilai maksimum sebesar 40 dengan nilai rata-rata sebesar 37,099. Nilai rata-rata 
sebesar 37,099 menunjukkan bahwa respon responden dalam menjawab pernyataan pada kuesioner cenderung merasa setuju pada masing-masing item pernyataan artinya keterampilan sosial cenderung tinggi, yang berarti responden memiliki keterampilan sosial yang baik. Standar deviasi pada variabel keterampilan sosial adalah sebesar 3,5547. Hal ini menunjukkan bahwa standar penyimpangan data terhadap nilai rata-ratanya adalah 3,5547.

Variabel pemahaman akuntansi memiliki nilai minimum sebesar 27 dan nilai maksimum sebesar 40 dengan nilai rata-rata sebesar 38,270. Nilai rata-rata sebesar 38,270 menunjukkan bahwa respon responden dalam menjawab pernyataan pada kuesioner cenderung merasa setuju pada masing-masing item pernyataan artinya pemahaman akuntansi cenderung tinggi, yang berarti responden memiliki pengertian pemahaman akuntansi yang baik. Standar deviasi pada variabel pemahaman akuntansi adalah sebesar 2,7092. Hal ini menunjukkan bahwa standar penyimpangan data terhadap nilai rata-ratanya adalah 2,7092.

Model regresi yang baik memiliki distribusi residual yang normal atau mendekati normal. Pengujian normalitas data dalam penelitian ini menggunakan uji statistik non-parametrik Kolmogrov Smirnov Test (K-S) dengan taraf signifikansi $5 \%$.

Tabel 2.

Hasil Uji Normalitas

\begin{tabular}{cccc}
\hline Persamaan & $\mathrm{N}$ & Kolmogrov Smirnov Z & $\begin{array}{c}\text { Asymp.sig (2- } \\
\text { tailed) }\end{array}$ \\
\hline $\mathrm{Y}=\alpha+\beta_{1} \mathrm{X}_{1}+\beta_{2} \mathrm{X}_{2}+\beta_{3} \mathrm{X}_{3}+\beta_{4} \mathrm{X}_{4}+\beta_{5} \mathrm{X}_{5}$ & 111 & 0,061 & 0,200 \\
\hline Sumber: Data diolah, 2018 & & &
\end{tabular}


Tabel 2 menunjukan bahwa nilai signifikansi persamaan tersebut sebesar 0,200 lebih besar dari 0,05. Hal ini berarti model regresi dalam penelitian ini berdistribusi normal.

Untuk mendeteksi ada tidaknya korelasi antar sesama variabel bebas dapat dilihat dari nilai tolerance dan nilai variance inflation factor (VIF). Jika nilai tolerance lebih dari 0,10 atau VIF kurang dari 10 maka dikatakan tidak ada multikolinearitas.

Tabel 3. Hasil Uji Multikolinearitas

\begin{tabular}{cccc}
\hline Variabel & Tolerance & VIF & Keterangan \\
\hline Pengenalan Diri & 0,643 & 1,556 & Bebas Multikolinearitas \\
Pengendalian Diri & 0,489 & 2,046 & Bebas Multikolinearitas \\
Motivasi & 0,457 & 2,190 & Bebas Multikolinearitas \\
Empati & 0,472 & 2,120 & Bebas Multikolinearitas \\
Keterampilan Sosial & 0,668 & 1,496 & Bebas Multikolinearitas \\
\hline
\end{tabular}
Sumber: Data diolah, 2018

Tabel 3 menunjukan bahwa nilai tolerance pada masing-masing variabel lebih besar dari 0,10 dan nilai VIF kurang dari 10 . Hal ini berarti model regresi terbebas dari gejala multikolinearitas

Model regresi yang baik adalah yang tidak mengandung gejala heterokedastisitas atau mempunyai varians yang homogen. Uji heterokedastisitas dalam penelitian ini dilakukan dengan uji Glejser. Suatu model regresi dikatakan bebas dari gejala heterokedastisitas apabila nilai signifikan masing-masing variabel lebih besar dari 0,05 . 
Tabel 4.

Hasil Uji Heterokedastisitas

\begin{tabular}{ccl}
\hline Variabel & Sig. & Keterangan \\
\hline Pengenalan Diri & 0,819 & Bebas Heterokedastisitas \\
Pengendalian Diri & 0,828 & Bebas Heterokedastisitas \\
Motivasi & 0,519 & Bebas Heterokedastisitas \\
Empati & 0,551 & Bebas Heterokedastisitas \\
Keterampilan Sosial & 0,804 & Bebas Heterokedastisitas \\
\hline
\end{tabular}

Sumber: Data diolah, 2018

Tabel 4 menunjukan bahwa semua variabel bebas berpengaruh terhadap variabel terikat sehingga dapat disimpulkan model regresi penelitian ini bebas dari gejala heterokedastisitas.

Hasil analisis dinyatakan dalam bentuk persamaan regresi linear berganda pada Tabel 5 sebagai berikut.

Tabel 5.

Hasil Analisis Regresi Linear Berganda

\begin{tabular}{|c|c|c|c|c|c|}
\hline \multirow[t]{2}{*}{ Variabel } & \multicolumn{2}{|c|}{$\begin{array}{c}\text { Unstandardized } \\
\text { Coefficients }\end{array}$} & \multirow{2}{*}{$\begin{array}{c}\text { Standardized } \\
\text { Coefficients } \\
\text { Beta }\end{array}$} & \multirow[t]{2}{*}{$\mathrm{T}$} & \multirow[t]{2}{*}{ Sig. } \\
\hline & $\mathrm{B}$ & Std. Error & & & \\
\hline Constant & 7,071 & 7,812 & & 0,834 & 0,403 \\
\hline Pengenalan Diri & 0,607 & 0,129 & 0,109 & 1,076 & 0,001 \\
\hline Pengendalian Diri & 0,731 & 0,215 & 0,157 & 1,141 & 0,000 \\
\hline Motivasi & 0,727 & 0,211 & 0,134 & 1,242 & 0,002 \\
\hline Empati & 0,826 & 0,316 & 0,103 & 3,738 & 0,000 \\
\hline Keterampilan Sosial & 0,854 & 0,390 & 0,163 & 3,382 & 0,000 \\
\hline Adjusted R Square & & & 0,748 & & \\
\hline F Hitung & & & 52,617 & & \\
\hline Signifikansi F & & & 0,000 & & \\
\hline
\end{tabular}

Sumber: Data diolah, 2018

Berdasarkan Tabel 5 variabel bebas berpengaruh simultan terhadap variabel terikat. Level of significant $(\alpha)$ yang digunakan adalah $5 \%(0,05)$. Nilai signifikansi $\mathrm{F}$ atau $p$-value pada tabel sebesar 0,000 yang lebih kecil dari 0,05. Hal ini menunjukan bahwa model regresi linear berganda layak digunakan sebagai alat analisis untuk menguji pengaruh variabel bebas pada variabel terikat. Ini berarti, seluruh variabel bebas (pengenalan diri, pengendalian diri, motivasi, empati, 
keterampilan sosial) dapat memprediksi atau menjelaskan fenomena pemahaman akuntansi di Fakultas Ekonomi dan Bisnis Universitas Udayana.

Berdasarkan nilai adj. $\mathrm{R}^{2}$ dapat diketahui berapa persen variabel dependen dapat dijelaskan oleh variabel independen, sedangkan sisanya dipengaruhi atau dijelaskan oleh variabel lain yang tidak dimasukkan dalam model penelitian. Berdasarkan Tabel 5 nilai adjusted $R^{2}$ sebesar 0,748 hal ini berarti $74,8 \%$ variasi pemahaman akuntansi dipengaruhi oleh variasi pengenalan diri $\left(\mathrm{X}_{1}\right)$, pengendalian diri $\left(\mathrm{X}_{2}\right)$, motivasi $\left(\mathrm{X}_{3}\right)$, empati $\left(\mathrm{X}_{4}\right)$, keterampilan sosial $\left(\mathrm{X}_{5}\right)$ serta sisanya sebesar 25,2\% dipengaruhi oleh variabel lain di luar model penelitian.

Berdasarkan Tabel 5 dapat disusun persamaan regresi linear berganda sebagai berikut.

$$
Y=7,071+0,607 X_{1}+0,731 X_{2}+0,727 X_{3}+0,826 X_{4}+0,854 X_{5}
$$

Konstanta regresi $(\alpha)$ sebesar 7,071 menunjukan bahwa apabila nilai pengenalan diri $\left(\mathrm{X}_{1}\right)$, pengendalian diri $\left(\mathrm{X}_{2}\right)$, motivasi $\left(\mathrm{X}_{3}\right)$, empati $\left(\mathrm{X}_{4}\right)$, keterampilan sosial $\left(\mathrm{X}_{5}\right)$ sama dengan nol, maka nilai pemahaman akuntansi $(\mathrm{Y})$ meningkat sebesar 7,071 satuan.

Koefisien regresi pengenalan diri $\left(\beta_{1}\right)$ sebesar 0,607 menunjukan bahwa variabel pengenalan diri mempunyai hubungan positif pada pemahaman akuntansi. Artinya, setiap kenaikan 1 satuan variabel pengenalan diri dengan asumsi variabel pengendalian diri, motivasi, empati dan keterampilan sosial konstan, maka akan meningkatkan pemahaman akuntansi sebesar 0,607 satuan.

Koefisien regresi pengendalian diri $\left(\beta_{2}\right)$ sebesar 0,731 menunjukan bahwa variabel pengendalian diri mempunyai hubungan positif pada pemahaman 
akuntansi. Artinya, setiap kenaikan 1 satuan variabel pengendalian diri dengan asumsi variabel pengenalan diri, motivasi, empati dan keterampilan sosial konstan, maka akan meningkatkan pemahaman akuntansi sebesar 0,731 satuan.

Koefisien regresi motivasi $\left(\beta_{3}\right)$ sebesar 0,727 menunjukan bahwa variabel motivasi mempunyai hubungan positif pada pemahaman akuntansi. Artinya, setiap kenaikan 1 satuan variabel motivasi dengan asumsi variabel pengenalan diri, pengendalian diri, empati, dan keterampilan sosial konstan, maka akan meningkatkan pemahaman akuntansi sebesar 0,727 satuan.

Koefisien regresi empati $\left(\beta_{4}\right)$ sebesar 0,826 menunjukan bahwa variabel empati mempunyai hubungan positif pada pemahaman akuntansi. Artinya, setiap kenaikan 1 satuan variabel empati dengan asumsi variabel pengenalan diri, pengendalian diri, motivasi, dan keterampilan sosial konstan, maka akan meningkatkan pemahaman akuntansi sebesar 0,826 satuan.

Koefisien regresi keterampilan sosial $\left(\beta_{5}\right)$ sebesar 0,854 menunjukan bahwa variabel keterampilan sosial mempunyai hubungan positif pada pemahaman akuntansi. Artinya, setiap kenaikan 1 satuan variabel keterampilan sosial dengan asumsi variabel pengenalan diri, pengendalian diri, motivasi dan empati konstan, maka akan meningkatkan pemahaman akuntansi sebesar 0,854 satuan.

Berdasarkan hasil pengujian pada Tabel 5 diketahui bahwa nilai $\beta_{1}=0,607$ dengan tingkat signifikansi sebesar 0,001 lebih kecil dari $\alpha=0,05$. Hal ini memiliki arti bahwa variabel pengenalan diri berpengaruh positif pada pemahaman akuntansi. Hal ini menerima hipotesis pertama $\left(\mathrm{H}_{1}\right)$ yang menyatakan bahwa pengenalan diri berpengaruh positif pada pemahaman akuntansi. 
Pengenalan diri yang baik berarti mahasiswa lebih memahami akan keberadaan diri mereka sendiri misalnya seperti mengetahui dengan benar akan kemampuan diri sendiri, berani tampil beda diantara teman-teman, mempunyai kemampuan untuk mendapatkan yang diinginkan dan memiliki kemauan untuk menyelesaikan pekerjaan dengan tanggung jawab dan pantang menyerah. Hal tersebut sesuai dengan penelitian yang dilakukan oleh Sidharta (2016) yang menyatakan bahwa pengenalan diri berpengaruh positif pada pemahaman akuntansi.

Berdasarkan hasil pengujian pada Tabel 5 diketahui bahwa nilai $\beta_{2}=0,731$ dengan tingkat signifikansi sebesar 0,000 lebih kecil dari $\alpha=0,05$. Hal ini memiliki arti bahwa variabel pengendalian diri berpengaruh positif pada pemahaman akuntansi. Hal ini menerima hipotesis kedua $\left(\mathrm{H}_{2}\right)$ yang menyatakan bahwa pengendalian diri berpengaruh positif pada pemahaman akuntansi.

Pengendalian diri yaitu kemampuan untuk menangani perasaan sehingga perasaan dapat diungkapkan dengan tepat, berhati-hati dan bertanggung jawab dalam bertindak guna mencapai hasil dan tujuan sesuai yang diinginkan. Pengaruh positif pengendalian diri pada pemahaman akuntansi menunjukan bahwa semakin baik keampuan seseorang dalam mengendalikan diri dan perasaannya akan dapat meningkatkan tingkat pemahaman akuntansi. Hasil penelitian ini sejalan dengan penelitian yang dilakukan oleh Julino (2013), Trisnawati dan Suryaningrum (2003) dimana dalam penelitiannya menyimpulkan bahwa pengendalian diri berpengaruh positif pada pemahaman akuntansi. 
Berdasarkan hasil pengujian pada Tabel 5 diketahui bahwa nilai $\beta_{3}=0,727$ dengan tingkat signifikansi sebesar 0,002 lebih kecil dari $\alpha=0,05$. Hal ini memiliki arti bahwa variabel motivasi berpengaruh positif pada pemahaman akuntansi. Hal ini menerima hipotesis ketiga $\left(\mathrm{H}_{3}\right)$ yang menyatakan bahwa motivasi berpengaruh positif pada pemahaman akuntansi.

Goleman (2003), dimana ia mengatakan bahwa motivasi adalah menggunakan hasrat yang paling dalam untuk menggerakkan dan menuntun seseorang menuju sasaran. Motivasi membantu seseorang mengambil inisiatif dan bertindak sangat efektif dan untuk bertahan menghadapi kegagalan dan frustasi. Dengan adanya motivasi, mahasiswa dapat menetapkan sasaran dan standar bagi dirinya sendiri sehingga akan terus semangat dan optimis untuk mendapatkan hasil yang diinginkan. Tanpa adanya motivasi maka mahasiswa akan hilang arah dalam mencapai tujuannya. Hasil penelitian ini sejalan dengan penelitian yang dilakukan oleh Horri dan Esti (2018) dan Manitri (2008) yang menyimpulkan bahwa motivasi berpengaruh positif pada pemahaman akuntansi.

Berdasarkan hasil pengujian pada Tabel 5 diketahui bahwa nilai $\beta_{4}=0,826$ dengan tingkat signifikansi sebesar 0,000 lebih kecil dari $\alpha=0,05$. Hal ini memiliki arti bahwa variabel empati berpengaruh positif pada pemahaman akuntansi. Hal ini menerima hipotesis keempat $\left(\mathrm{H}_{4}\right)$ yang menyatakan bahwa empati berpengaruh positif pada pemahaman akuntansi.

Empati, yaitu kemampuan dalam bergaul, mampu menangkap sinyal sinyal sosial yang tersembunyi dan mengisyaratkan apa yang dibutuhkan atau dikehendaki orang lain. Mengenali emosi orang lain berarti kita memiliki empati 
terhadap apa yang dirasakan orang lain. Penguasaan mahasiswa akan keterampilan ini dapat membuat komunikasi dengan orang lain menjadi lebih efektif. Empati dapat ditunjukkan dengan memiliki banyak teman, dapat menempatkan diri pada posisi orang lain serta tidak canggung ketika berbicara dengan orang yang tidak dikenal. Pengaruh positif empati pada pemahaman akuntansi menunjukan bahwa semakin tinggi empati dalam diri mahasiswa akan memberikan informasi kepada mahasiswa itu sendiri yang selanjutnya informasi tersebut dalam membantu dalam memahami berbagai perihal, khusunya pemahaman akuntansi. Hasil penelitian ini sejalan dengan penelitian yang dilakukan oleh Satria (2017) dan Tjun (2009) yang menyimpulkan bahwa empati berpengaruh positif pada pemahaman akuntansi.

Berdasarkan hasil pengujian pada Tabel 5 diketahui bahwa nilai $\beta_{5}=0,854$ dengan tingkat signifikansi sebesar 0,000 lebih kecil dari $\alpha=0,05$. Hal ini memiliki arti bahwa variabel keterampilan sosial berpengaruh positif pada pemahaman akuntansi. Hal ini menerima hipotesis kelima $\left(\mathrm{H}_{5}\right)$ yang menyatakan bahwa keterampilan sosial berpengaruh positif pada pemahaman akuntansi.

Keterampilan sosial adalah kemampuan menangani emosi dengan baik ketika berhubungan dengan orang lain, memimpin, bermusyawarah, menyelesaikan perselisihan dan bekerjasama dalam tim. Keinginan untuk maju dari dalam diri mahasiswa akan menimbulkan semangat dalam meningkatkan kualitas mereka. Semakin tinggi keterampilan sosial pada diri mahasiswa maka dapat meningkatkan pemahaman akuntansi. Hasil penelitian ini sejalan dengan penelitian yang dilakukan oleh Manansal (2013) dan Wiwin dan Ernawati (2007) 
Made Sukma Mutiara Paramita Sari dan Dewa Gede Wirama. Pengaruh ...

yang menyimpulkan bahwa keterampilan sosial berpegaruh postif pada pemahaman akuntansi.

\section{SIMPULAN}

Berdasarkan pembahasan hasil penelitian di atas, dapat disimpulkan bahwa pengenalan diri berpengaruh positif pada pemahaman akuntansi. Hal ini berarti semakin tinggi pengenalan diri seorang mahasiswa, maka semakin tinggi pemahaman akuntansinya. Pengendalian diri berpengaruh positif pada pemahaman akuntansi. Hal ini berarti semakin tinggi pengendalian diri seorang mahasiswa, maka semakin tinggi pemahaman akuntansinya. Motivasi berpengaruh positif pada pemahaman akuntansi. Hal ini berarti semakin tinggi motivasi seorang mahasiswa, maka semakin tinggi pemahaman akuntansinya. Empati berpengaruh positif pada pemahaman akuntansi. Hal ini berarti semakin tinggi empati seorang mahasiswa, maka semakin tinggi pemahaman akuntansinya. Keterampilan sosial berpengaruh positif pada pemahaman akuntansi. Hal ini berarti semakin tinggi keterampilan sosial seorang mahasiswa, maka semakin tinggi pemahaman akuntansinya. Saran yang dapat diberikan pada peneliti selanjutnya penelitian ini diharapkan mampu menjadi referensi bagi yang tertarik meneliti topik serupa dan disarankan menggunakan variabel lain yang tidak digunakan dalam penelitian ini. Penggunaan objek penelitian yang berbeda juga dapat dilakukan guna menambah variasi dan jumlah sampel penelitian agar nantinya hasil yang diperoleh lebih representatif. 


\section{REFERENSI}

Agrawal, N and Khan, M. (2015). Roles of Emotional Intelligence and Sprituality on Employee's Well-Being. The International Journal of Indian Psychology, 2(4), 6-15.

Ashkanasy, N., Hartel, C., and Davis, C. (2002). Diversity and emotion: the new frontiers in organizational behavior research. Journal of Management, 28(3).

Azizollah, A. (2013). Relation Between Emotional Intelligence, Spritual Intelligence, and Student academic Achievement. World of Sciences Journal, $1(8)$.

Bakhtiarpor, S. (2009). Predicting the Students' Academic Achievement based on the Intelligence Quotient, Academic Experiences, and Demographic Variables in the university of AhvazNo Title. Journal of New Finding in Psychology, 5(26).

Bay, D., and Mckeage, K. (2006). Emotional Intelligence in Undergraduate Accounting Students: Preliminary Assessment. Accounting Education: An International Journal, 15(4).

Cetin, B. (2016). Academic Motivation and Approaches to Learning In Predicting College Students' Academic Achievement: Findings From Turkish and US Samples. Journal of College Teaching \& Learning, 13(1).

Constanty, A. P. (2017). Pengaruh Kecerdasan Emosional Terhadap Tingkat Pemahaman Akuntansi Di Lingkungan Universitas PGRI Yogyakarta. Jurnal Ekonomi.

Durgut Mehmet, P., Gerekan Bilal, P., and Pehlivan Abdülkadir, P. (2013). The Impact of Emotional Intelligence on the Achievement of Accounting Subject. International Journal of Business and Social Science, 4(13).

Fahrianta, A. Y., dan Syam, S. A. S. (2012). Pengaruh Kecerdasan Emosional dan Kecerdasan Spritual Mahasiswa Akuntansi Terhadap Tingkat Pemahaman Akuntansi. Jurnal Sosioscienta Kopertis Wilayah XI Kalimantan, 4(2).

Fallan, L., and Opstad, L. (2014). Beyond Gender Performance in Accounting: Does Personality Distinction Matter? Accounting Education: An International Journal, 23(4).

Fanikmah, D. A. (2016). Pengaruh Kecerdasan Emosional dan Minat Belajar terhadap Pemahaman Akuntasi. Jurnal Ilmu Dan Riset Akuntansi, 5(7). 
Fred, P., Guina., S., and Alford, S. (2012). Illustration in Financial Accounting Textbooks: Function and Placement Interact to Affect Student Learning. Issues in Accounting Education, 27(4).

Goleman, D. (2003). Kecerdasan Emosional.

Horri, M., dan Esti, H. A. (2018). Pengaruh Kecerdasan Emosional Terhadap Tingkat Pemahaman Akuntansi Pada Mahasiswa Akuntansi di Universitas Dr. Soetomo. Jurnal Analisa Akuntansi Dan Perpajakan. Universitas Dr Soetomo.

Jones, G. (2009). The Value of Incorporating Emotional Intelligence Skills in the Education of Accounting Students. Australasian Accounting Business and Finance, 3(4).

Julino, S. (2013). Pengaruh Kecerdasan Emosional Terhadap Tingkat Pemahaman Akuntansi Pada Mahasiswa Akuntansi Fakultas Ekonomi Universitas Tanjungpura. Jurnal Audit Dan Akuntansi Fakultas Ekonomi Universitas Tanjungpura., 2(2).

Khaef, F., and Ahmadali, D. M. (2003). EI dimensions. Management and Development Journal, 18.

Khaledian, M., Saber, A., and Kayhan, P. (2013). The relationship between accounting students' emotional intelligence (EQ) and test anxiety and also their academic achievements. European Journal of Experimental Biology, $3(2)$.

Mahdi Salehi, M., Zadeh, A., Ghaderi, A., and ZhianTabasi, A. (2016). A Study of the Effect of Education and Academic Environment on Emotional Intelligence on Accounting Students in Iran. International Education Studies, 9(1).

Manansal, A. A. (2013). Kecerdasan Emosi Mahasiswa Akuntansi Fakultas Ekonomi dan Bisnis Pengaruhnya Terhadap Tingkat Pemahaman Akuntansi. Jurnal Emba, 1(3).

Manitri, C. S. olaudio. (2008). Pengaruh Kecerdasan Emosional Mahasiswa Akuntansi Terhadap Tingkat Pemahaman Akuntansi. Jurnal Ekonomi.

Melandy, R. (2007). Sinkronisasi Komponen Kecerdasan Emosional dan Pengaruh Terhadap Tingkat Pemahaman Akuntansi Dalam Sistem Pendidikan Tinggi Akuntansi. Simposium Nasional Akuntansi X.

Modassir, A. (2008). Relationship of Emotional Intelligence with Transformational Leadership and Organizational Citizenship Behavior. 
International Journal of Leadership Studies, 4(1).

Mulyani, S. (2017). Pengaruh Pengendalian Diri, Kepercayaan Diri, Kecerdasan Emosional, Kecerdasan Spiritual Dan Perilaku Belajar Terhadap Tingkat Pemahaman Akuntansi. Jurnal Umrah.

Nuraini, M. (2007). Pengaruh Kecerdasan Emosional dan Minat Belajar Mahasiswa Akuntansi Terhadap Tingkat Pemahaman Akuntansi. Jurnal BETA.

Pan, P., and Hector, P. (2011). Market relevance of university accounting programs: Evidence from Australia. Accounting Forum, 36.

Putri, A. D. I G. A. M. (2008). Implikasi Riset Akuntansi Keperilakuan Terhadap Pengembangan Akuntansi Manajemen. Jurnal Ilmiah Akuntansi Dan Bisnis Universitas Udayana, 3(2).

Rachmi, F. (2010). Pengaruh Kecerdasan Emosional, Kecerdasan Spiritual, dan Perilaku Belajar Terhadap Pemahaman Akuntansi. Jurnal Pendidikan Akuntansi.

Rahayu, S., Anna, Y. D., dan Said, L. (2008). Pengaruh Kecerdasan Emosional Terhadap Tingkat Pemahaman Akuntansi. Jurnal Bisnis, Manajemen \& Ekonomi, 9(4).

Satria, M. R. (2017). Pengaruh Kecerdasan Emosional Terhadap Tingkat Pemahaman Akuntansi Pada Mahasiswa Akuntansi di Kota Bandung. Jurnal Ekonomi, 1(1).

Sidharta, H. Y. (2016). Pengaruh Kecerdasan Emosional terhadap Tingkat Pemahaman Akuntansi (Studi Kasus pada Mahasiswa Akuntansi Universitas Jember). Jurnal Akuntansi.

Stein, S. ., dan Howard. (2002). Prinsip Dasar Kecerdasan Emosional Meraih Sukses.

Tjun, L. T. (2009). Pengaruh Kecerdasan Emosional Terhadap Tingkat Pemahaman Akuntansi Dilihat Dari Persfektif Gender. Jurnal Akuntansi, $1(2)$.

Trisnawati, I. I., dan Suryaningrum, S. (2003). Pengaruh Kecerdasan Emosional Terhadap Tingkat Pemahaman Akuntansi. Simposium Nasional Akuntansi VI.

Wibowo, B. (2002). Sharpehing Our Concept And Tools. 
Widyawati, P. G., Immanuela, I., dan Handayani, D. (2014). Pengaruh Kecerdasan Emosional, Perilaku Belajar dan Budaya terhadap Tingkat Pemahaman Akuntansi dengan Kepercayaan Diri sebagai Variabel Moderating. Jurnal Riset Manajemen Dan Akuntansi, 2(1).

Wiwin, W., dan Ernawati, nababan A. (2007). Pengaruh Kecerdasan Emosional mahasiswa Terhadap Tingkat Pemahaman Akuntansi di Universitas Wijaya Kusuma Surabaya. Jurnal Ekonomi Manajemen Akuntansi, 5(3).

Wiyono, M. W. (2012). Pengaruh Kecerdasan Emosional Terhadap Tingkat Pemahaman Akuntansi. Jurnal WIGA, 2(2).

Yanti, N. (2014). Analisis Faktor-Faktor yang Mempengaruhi Mahasiswa Akuntansi dalam Pemilihan Karir Menjadi Akuntan Publik (Studi empiris pada Perguruan Tinggi Negeri dan Swasta di Pekanbaru). Jurnal FEKON, $1(2)$.

Yulisa Febri, Kamaliah, dan H. R. A. (2014). Pengaruh Kecerdasan Emosional dan Kepribadian Terhadap Tingkat Pemahaman Akuntansi (Studi Empiris pada mahasiswa Akuntansi fakultas ekonomi universitas Riau). Jurnal Online Mahasiswa Bidang Ekonomi, 1(2). 